\title{
The fibrinolytic mechanism in haemostasis: A review
}

\author{
J. L. STAFFORD
}

From the Haematology Department, St. George's Hospital, London

Circulating blood must remain fluid: if it does not, the culminating thrombosis is a pathological event with definable sequelae. It is unlikely, on teleological grounds, that such a defensive mechanism should exist only in moments of peril. Hence a general if tacit assumption has developed that clotting is not an episodic but a continuous process (Macfarlane, 1945; Roos, 1957) which normally is never allowed to progress to a physical end-point unless vascular integrity is in jeopardy. But if the maintenance of fluidity, in circumstances which permit the possibility of clotting, is a physiological necessity, then one must conceive a homeostatic system in which equilibrium is maintained by the balance of equal yet opposing forces (Astrup, 1962). It is in this context of a continuous physiological requirement, as distinct from episodic pathological changes, that fibrinolysis must be judged. Moreover, we are dealing with a biological system dependent upon protein 'activity' which can be expressed only as a resultant of these balanced opposing forces: the function of single protein moieties cannot be measured in isolation.

It is important to appreciate that haemostasis is governed, also, by the effects of both time and motion: in physiology, the persistence of free flow must directly influence the sequence of events. Study in vitro can never simulate the interplay of forces engaged in this endless yet beneficial conflict There is one further point to be borne in mindo intravascular thrombosis in pathology is primarily a venous phenomenon with occlusive effects on aN moving stream, whereas the minor wear-and-teaf thrombotic episodes acknowledged to be incidentaly to everyday life occur largely in the capillary bedo parts of which, intermittently, may be shunted out of the general circulation and thus become stagnantos

The physiological significance of fibrinogets appears to depend solely on its polymerization to fibrin followed by gelation and subsequent con? densation (clot retraction). This chain reaction i\$ governed, and the fluidity of blood maintained, byo two proteolytic enzymes acting in opposition thrombin and plasmin, each derived from a naturally circulating plasma precursor prothrombin $0 \Phi^{\circ}$ plasminogen (Figure 1).

Study of the clinical effects of enhanced polyo merization is relatively simple because a clot can be्ह seen and felt. The opposite is not so, for fibrinogeno? lysis in vivo (degradation of fibrinogen while still i $\overrightarrow{\mid \vec{D}}$ solution in contrast to destruction of fibrin) cap only be assessed in terms of haemostatic failure? minimal enhancement is probably a natural even? for which there is some evidence of diurnal variation (Fearnley, Balmforth, and Fearnley, 1957), but grades of severity are difficult to define until absolute
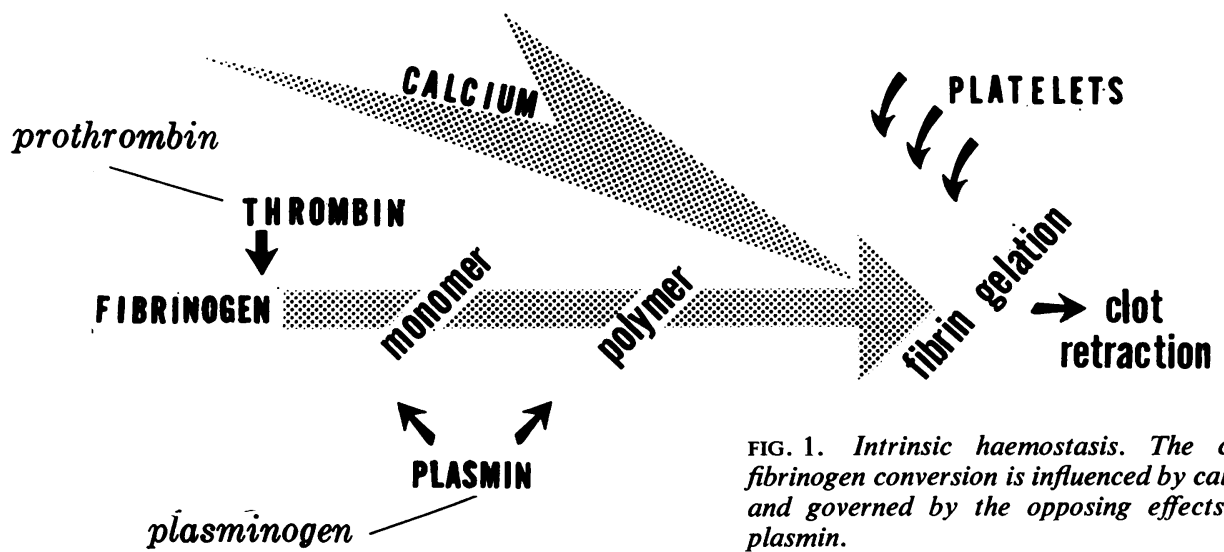

FIG. 1. Intrinsic haemostasis. The chain reaction fibrinogen conversion is influenced by calcium and platelet and governed by the opposing effects of thrombin and plasmin. 
reduction in circulating fibrinogen concentration becomes measureable. Such excessive fibrinolysis can, however, be observed in two different pathological contexts: enhancement of the lytic mechanism may lead to systemic defibrination and thence to bleeding or, in contrast, actual thrombosis may be restricted and even, in suitable circumstances, corrected.

\section{SURVIVAL OF FIBRINOGEN}

For the purpose of this review it has been necessary to assume that the elaboration of fibrin and the process of its dissolution occur constantly, any such conception implying a perpetual consumption of the principal substrate. The biological half-life of fibrinogen seems to be shorter than that of most plasma proteins (this may also be true of prothrombin, factors V, VIII, and less readily assayable clotting proteins); the fibrinogen half-life has been estimated in man to be four to six days (Madden and Gould, 1952; Hammond and Verel, 1959) and somewhat less in dogs (Lewis, Ferguson, and Schoenfeld, 1961) and rabbits (Cohen, Holloway, Matthews, and McFarlane, 1956). This method of assessment may not be valid, however, as isotopic labelling of fibrinogen and its re-introduction into the blood stream demonstrably leads to sequestration: moreover, Lewis et al. (1961) have shown that systemic administration of coumarin or heparin does not prolong the half-life although manifestly altering intrinsic coagulation sequences.

\section{THE VASCULAR MILIEU}

Whilst it is convenient to discuss fibrinolysis or coagulation as apparently distinct processes, it is axiomatic that the physiological significance of the one mechanism can be judged only in terms of the other: and any apparent pathological enhancement of either mechanism must also be viewed in the possible context of simultaneous retardation of the other.

Figure 2 shows that each intrinsic system is governed by the interaction of globulins in biological solution and these, in turn, are influenced by their relative molecular concentration and their proximity to metallic ions and to cell and vessel surfaces. In certain circumstances, to these features must be added the effect of flow rate and, should fibrinogen ever polymerize, the apparently specific yet selective attraction of the surface so formed for some of the moieties taking part, whereby their local effect is concentrated.

\section{FACTORS TAKING PART}

Plasmin and thrombin are formed whenever impairment of vascular integrity permits the entry of pre-formed tissue activators, 'extrinsic activation'.

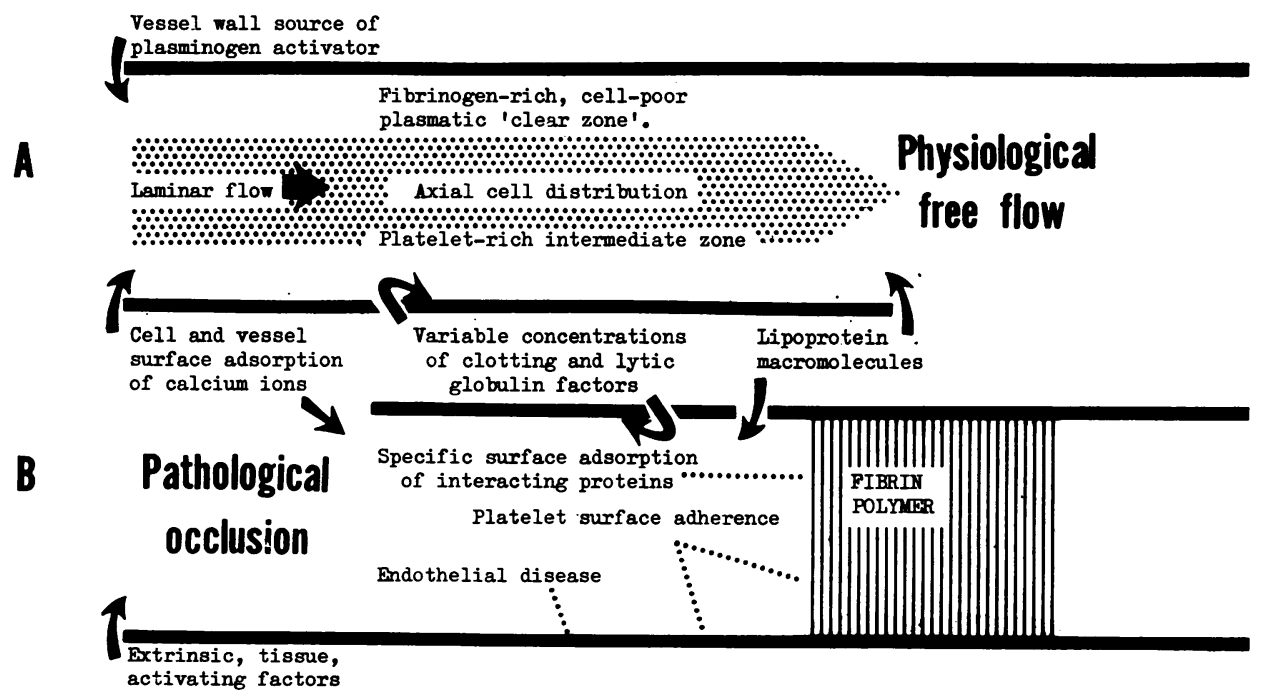

FIG. 2. The effect of environment on the haemostatic equilibrium.

$A$ A theoretical venule or capillary, free from the influence of turbulence or pulsatile flow.

$B$ A similar sized vessel in witich occlusion, endothelial disease, or encroachment by tissue factors may alter the flow pattern. 
If factors normally in equilibrium within the vascular tree are in any way stimulated, 'intrinsic activation', this is assumed to be initiated by the so-called contact factors (XII and XI) when thrombin is formed, and by the release of activator substances from the vessel wall whenever plasminogen is to be converted to plasmin.

Intrinsic activation of fibrinolysis or coagulation each comprises three preparatory phases leading to the establishment of potent proteolytic enzymes: in a moving stream this may be ephemeral but with stagnation the effect can be explosive and, through autocatalysis, progressive within the limits imposed only by the local concentration of precursors (Figure 3). It must be emphasized that this discussion takes no account of any encroachment of the circulation by tissue fluids, this being relevant only in the pathological context of vascular damage. There is no convincing evidence to implicate extrinsic factors in natural intravascular homeostasis, but the entrance of a small amount of tissue fluid into the circulation is probably constant as witnessed by the presence in plasma of small amounts of anti-tissue-thromboplastins. In fibrinolysin stimulation there is at present no evidence to suggest the constant circulation of anti-activator substances.

Whilst there is detailed knowledge of contact activation and the sequential generation of thromboplastin (prothrombin activator), phenomena which may be studied because the time taken is sufficiently slow, there is no such knowledge about plasminogen activator which may lurk, pre-formed, in the vascular endothelium but, equally probably, may be generated locally yet too rapidly for current methods to measure.

FACTORS COMMON TO CLOTTING AND LYSIS Some factors directly affect both coagulation and fibrino-

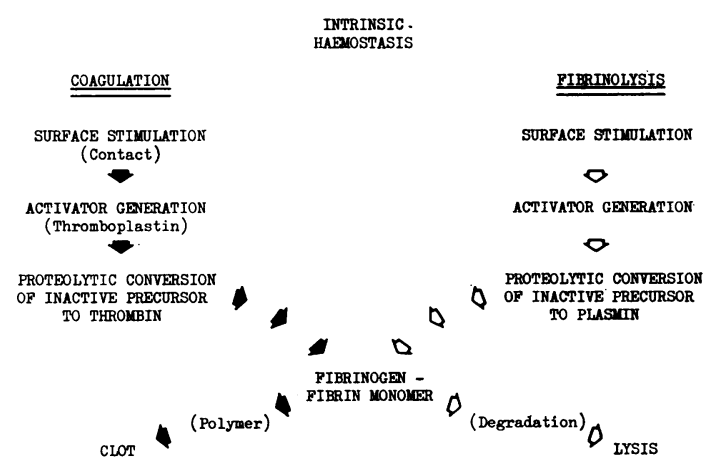

FIG. 3. Intrinsic haemostasis. Both fibrinolysin activation and clot generation may pass through three similar phases, in which event, whilst thromboplastin generation takes several minutes, the time taken to elaborate plasminogen activator is too short to measure. lysis, or influence the stability of the fibrinogen molecule during its polymerization. These include $\overrightarrow{\vec{S}}$ ionic calcium, the globulin fibrin-stabilizing factor(Lorand, 1961; Laki, 1962) and the ubiquitous platelets (Figure 4). Each of these acts upon clot $\overline{\bar{c}}$ generation or the formation and function of plasmin; $\widetilde{\Phi}$ each may also influence the vessel wall in its release of plasminogen activator or in its association ${ }^{\infty}$ with the contact factors. They represent the lowest $\vec{O}$ common multiples of the coagulation-fibrinolysin $\overrightarrow{\vec{A}}$ equation.

Any constant interplay between lysis and coagulation must employ either a retarding mechanism? which halts fibrinogen polymerization before the $\vec{v}$ complexed molecules come out of solution-or degradation of fibrin monomer-or means whereby $N$ the fibrin polymer is immediately degraded before ito becomes large enough to attract platelet adherence $?$ or to obstruct flow. These events, which are occurring $(D)$ simultaneously, involve proteolytic sequences and $\frac{\mathbb{D}}{0}$ thus relatively small, presumably intensely electro- $\mathbb{\mathbb { D }}$ negative, peptide radicles are constantly being detached from their parent structures. This is $\frac{\mathbb{C}}{-}$ most easily assessed in relation to the by-products of $\vec{\bullet}$ thrombin degradation of fibrinogen (fibrinopeptides) $\stackrel{\odot}{\triangleright}$ or of plasmin degradation of fibrin (fibrin lysates): doubtless this is true at all links in chain reactions where an inactive protein precursor is converted into active proteolysis.

Macfarlane (1964) likens the sequential generation $\frac{0}{\varnothing}$ of thromboplastin and prothrombin-thrombin con- $\varrho$ version to a radio amplifier circuit. Using this $\overrightarrow{\bar{O}}$ analogy, the transitory accumulation of peptide 3 by-products may serve to check or limit the reaction as a whole, on the principle of negative feed-back. Thus some of the functions loosely termed anti- $\overline{0}$ thrombin or anti-plasmin result from the reaction: which they serve to restrict. Environmental features 3 . may thus be disturbed. As this biological phenomenon occurs in the vascular bed, it is relevant to note $₹$ that contact factors are associated with thoseo governing vascular permeability (Spector, 1957; Margolis, 1958a and b; Mill, Elder, Miles, and Wilhelm,으․ 1958) and pain (Keele, 1957) and with bradykinin (Lewis, 1962) whilst the negatively charged fibrino- $O$ peptides may influence the migration of leucocytes $N$ (Sawyer and Pate, 1953) and fibrin lysates mayN్ట్ antagonize histamine (Copley, 1962).

The Hageman factor (XII) may indeed be $a$ principal connecting link in the homeostatic balance? between lysis and polymerization, but, probably because only a minute amount of this protein is utilized, there is no convincing evidence that it is an essential prerequisite in intrinsic fibrinolysis. Its role in thromboplastin generation is enzymic (Ratnoff, $\frac{\stackrel{?}{\mathbb{P}}}{\mathrm{O}}$ Davie, and Mallett, 1961) and the possibility of $a_{\frac{O}{\sigma}}$ 


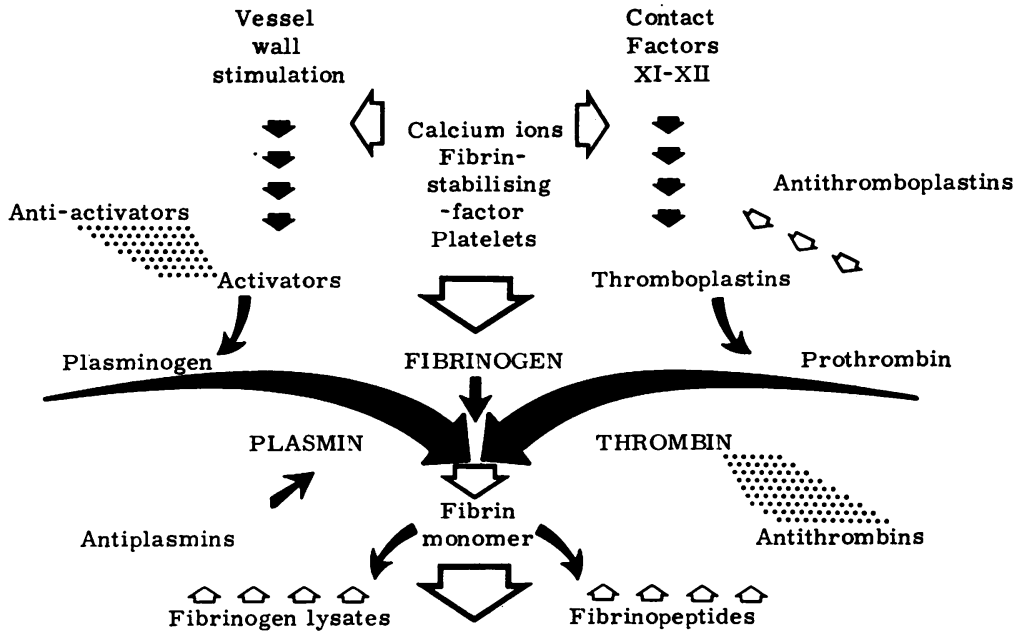

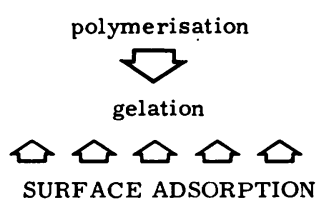

similar role in fibrinolysis has been reviewed by Niewiarowski and Prou-Wartelle (1959) and by Iatridis and Ferguson $(1961,1962)$.

ACTIVATORS OF PLASMINOGEN This activation is a proteolytic reaction and the resultant plasmin has a somewhat smaller molecule than its precursor plasminogen. The presence in plasma of a minute trace of activator is probably normal (Fearnley, 1953; Sawyer, Fletcher, Alkjaersig, and Sherry, 1960), but this is so readily released from blood vessel walls after relatively trivial stress that it is difficult to be certain. Nor is it yet known whether all plasminogen activation follows a similar sequence in man. Physical exercise and adrenaline injection (Biggs, Macfarlane, and Pilling, 1947), emotional or traumatic shock (Macfarlane and Biggs, 1946), and the administration of pyrogens or drugs, such as nicotinic acid, which act on vessel walls, will each release activator into the plasma. The principal site for plasma activator formation appears to be the vessel wall itself (Kwaan, Lo, and McFadzean, 1957; Todd, 1959) but other forms of plasminogen activator are found in almost all body tissues and secretions (Astrup and Permin, 1947; Albrechtsen, 1957) with the possible exception of liver where plasminogen itself is elaborated. Urokinase, found in normal urine (Williams, 1951), is the form most readily available for study and, as it appears in
FIG. 4. The various factors which maintain the intrinsic haemostatic equilibrium, ionic calcium, fibrin stabilizing factor, and platelets being common denominators.

The physiological role played by antithrombins and antiactivators is conjectural: fibrinogen lysates and fibrinopeptides may exert a retarding influence, and the surface presented after polymerization has a crucial effect on subsequent events.

equal amounts in the bladder and the renal pelvis, there is speculation about its origin from the blood stream or from functioning kidney tissue. The high concentration of activator in prostatic and lung tissue can become clinically significant if these are roughly handled during operation.

OTHER ACTIVATORS In addition to naturally occurring factors, artificial activators have been studied. Some, such as chloroform (Tagnon, 1942), achieve this effect by reducing antiplasmin activity. The bacterial extract, streptokinase, from the haemolytic streptococcus, was the first to be introduced (Tillett and Garner, 1933) and is of clinical importance because it can now be given intravenously. Of bovine substrates, streptokinase seems to require a co-factor, pro-activator, before it can convert plasminogen: this may also be true in the human or, in this instance, plasminogen may be capable of serving in both roles (Ablondi and Hagan, 1957; Kline, 1960).

Finally, plasmin itself can activate plasminogen (autocatalysis) as can other proteolytic enzymes such as trypsin, a matter of consequence in acute pancreatitis.

ANTI-ACTIVATORS The function of plasminogen activator is also subject to the retarding influence of inhibitor proteins in vitro. This may have little or no 
significance in the normal circulation but the rapid development of anti-activator activity in shed blood, after its contact with glass, can vitiate laboratory results. Plasminogen activator is stable in whole blood or plasma and Flute (1960) clearly demonstrated that its apparent lability, as shown by Fearnley and Lackner (1955), is due to the rise in the function of anti-activator rather than to any reduction in activator activity. Careful avoidance of contact with wettable surfaces and a rigidly applied cold technique, during which the plasma sample is retained between 0 and $4^{\circ} \mathrm{C}$., reduce the development of anti-activator function to a minimum.

PLASMINOGEN This is a naturally circulating inactive beta-globulin with a molecular weight which may be as high as 140,000 (Shulman, Alkjaersig, and Sherry, 1958) or as low as 83,800 (Davies and Englert, 1960). Sgouris, Inman, McCall, Hyndman, and Anderson (1960) have described a technique for its preparation from the Cohn fraction III paste usually discarded in the preparation of gamma globulin from outdated blood (Oncley, Melin, Richert, Cameron, and Gross, 1949). It is stable in plasma and comes down with the 'euglobulin' fraction after dilution with acidified distilled water: the plasma euglobulin fraction or the fibrinogenfree serum euglobulin fraction can thus be utilized to provide a convenient laboratory source (Howell, 1963; Hawkey and Stafford, 1964).

The plasminogen molecule is probably larger than plasmin (Shulman et al., 1958), and there is thus a direct analogy with the relation in size of prothrombin to thrombin and of fibrinogen to fibrin. The conversion of plasminogen to plasmin appears to involve the removal of a moiety so laying bare a centre of activity: as in other biological systems a relatively small alteration in configuration may radically change protein function. Kline $(1960)$ is convinced that the proactivator necessary in the streptokinase reaction is plasminogen in another guise, in which either two active centres are uncovered or a different surface radicle is exposed so that two separate reactions may occur.

Plasminogen may have a specific affinity for fibrin (Back, Ambrus, and Markus, 1959) whereby it can be adsorbed to the fibrin surface; it may be, however, that it is the activator factors which alone possess this affinity. The fact that one or both can be concentrated by specific attraction to fibrin surfaces leads to the ready conversion of plasmin at the site where it is required yet with minimum influence from anti-plasmins.

PLASMIN In vitro this proteolytic enzyme has substrate specificity for both fibrinogen and fibrin
(Ratnoff, 1953; Ambrus and Markus, 1960): it will also digest certain protein components of the coagulation system-factor V, factor VIII (antihaemophilic), and prothrombin (Fletcher, Alkjaersig and Sherry, 1959; Donaldson, 1960; McNicol, Douglas, and Bayley, 1962). Its digestion of casein permits comparative measurement of activity, but as this is scarcely physiological, many different methods have been devised to assess the lysis of fibrin itself under controlled conditions.

Such laboratory methods are based either on external visible lysis of a fibrin plate (Astrup and Mullertz, 1952) when the proteolytic enzyme is added from outside, or on internal lysis promoted by incorporating the fibrinolytic agent within the clot itself. In the latter, the breakdown of ${ }^{131}$ I-fibrinogen can be measured by the iodine released (Shulman and Tagnon, 1950; Clement and McNicol, 1959) or a standardized clot (Christensen, 1949), containing red cells (Blix, 1962; Howell, 1964a), can be formed with standardized substrates: this approach at least simulates the spatial relationship between the various interacting components and the end-point $\mathbb{\mathscr { C }}$ can be judged as the time taken for total lysis $\vec{\varphi}$ (Hawkey and Stafford, 1964).

Plasmin apparently digests fibrinogen by hydrolysis of peptide bonds as arginine and lysine residues: synthetic substrates containing esters of these aminoacids may act as competitive inhibitors (Troll, Sherry, and Wachman, 1954). The remarkable capacity for attacking fibrin in vivo is inhibited by certain plasma proteins collectively called antiplasmins.

ANTIPLASMINS (INHIBITORS) Normal plasma or serum exhibits a considerable excess of antiplasmin activity, perhaps thirty-fold the potential quantity of plasmin (Norman, 1958; Fletcher et al., 1959); this is relevant to any discussion of a dynamic equilibrium. Such inhibitory mechanisms may also have a beneficial tendency to restrict plasmin to its digestion of fibrin. At least two antiplasmin plasma proteins exist: an alpha 1 globulin and a more rapidly acting alpha 2 globulin (Norman and Hill, 1958). Platelets also exert antiplasmin activity. O

The reactions with plasmin of these circulating $N$ inhibitors are markedly affected if the protein N substrate, fibrin, is present. This is because fibrin is $\omega$ more avid for the active site on plasmin than is anti-plasmin: conversely fibrinogen, although also a substrate, seems to be less avid (Celander and Guest, $\stackrel{\mathbb{D}}{+}$ 1957). Thus a homeostatic bias promotes the destruction of fibrin but permits the preservation of fibrinogen.

The three-dimensional significance of the surface $\frac{\stackrel{\rho}{\mathbb{D}}}{\mathbb{1}}$ provided by formed fibrin is the basis for an attract- $\varnothing$ 
ive hypothesis introduced by Sherry and his colleagues to explain the physiological mechanism involved in clot destruction or thrombolysis (Sherry, Fletcher, and Alkjaersig, 1959a; Sherry, Lindemeyer, Fletcher, and Alkjaersig, 1959b). In the interstices of thrombi, because of the physical affinity of plasminogen for fibrin, the local concentration of plasminogen is relatively high whilst that of antiplasmin is relatively low, unless there is a pathological excess of platelets. Thus, when circulating plasma activator diffuses into an area of thrombosis, the intrinsic clot plasminogen is activated and the resultant plasmin, unimpeded by antiplasmin, is readily able to digest its fibrin substrate. Any diffusion of plasmin back into the general circulation is relatively innocuous because plasma antiplasmins serve to protect fibrinogen in solution.

The difficulty of distinguishing between activation of one factor and the inhibition of its antagonist has led to somewhat complex explanations of what may be a relatively simple interplay of plasma proteins. This difficulty is most apparent when protein interaction is related to adjacent non-protein components: ionic calcium classically enhances coagulation yet Fearnley (1961) has reported it to inhibit fibrinolysis. Bruce (1964) has shown, however, that calcium probably influences plasmin function by activating the antiplasmin inhibitors.

\section{THE PHYSICAL CHARACTER OF FIBRIN}

Whatever might be thought of the physiological role played by plasmin the topic is not readily amenable to scientific proof: most of the current knowledge of fibrinolysis has been gleaned from observed pathology, when either coagulation or fibrinolysis has established hegemony over the other.

In pathological states of venous or arterial thrombosis the adsorptive capacity of the fibrin surface is apparently decisive: furthermore, the coincidence of endothelial abnormality or the consequence of occlusion results in a changed flow pattern. In these circumstances the interplay of protein moieties is conditioned by features which are absent from normal physiology. At this point in discussion it is thus necessary to consider the physical qualities of the fibrinogen molecule and of its polymer (Scheraga, 1958).

Reference to the work of Hall and Slayter (1959) and to the many papers by Laki $(1951,1962)$ and by Lorand (1961) permits some visualization of the fibrin surface. The fibrinogen molecule possibly comprises a spiral chain with three separated areas of more complex folding. It is converted after contact with thrombin into a fibrin monomer and then polymerized. It is not known at which points plasmin exerts its proteolytic effects but, as this enzyme is also fibrinogenolytic, changes may perhaps occur during the early phase if enough plasmin exists at these sites. As polymerization proceeds, both end-to-end and side-to-side bonding occurs. Ultimately the fibrin band or filament provides a surface to which plasminogen activator and thrombin are attracted. Whether the plasminogen molecules are involved because they are trapped in the mesh or also because of specific adsorption is still not known.

The surface attraction of these moieties is depicted in relation to a broad band of fibrin molecules polymerized by side-to-side bonding (Figure 5). Ionic calcium, platelets, and the serum globulin 'fibrin-stabilizing factor (fsf)' seem to enjoy some special relationship denied to the other circulating factors. The fibrin-stabilizing factor, now known as factor XIII, serves in the process of conversion of the early monomeric fibrin molecule, which is urea-soluble, to the urea-insoluble polymer capable of clot retraction. Calcium may promote additional linkages between factor XIII and these fibrin molecules, rendering them less susceptible to attack by plasmin (Bickford and Sokolow, 1961).

In the normal course of events, the fibrin monomers will condense to form fibrin polymer, assuming that sufficient thrombin is present. Excess free plasmin, if it is in sufficient concentration to nullify the inhibitory power of the antiplasmins, will attack fibrinogen as well as fibrin, and the polypeptide fragments so formed can physically interfere with any polymerization taking place in the immediate vicinity. The polypeptide fragment or breakdown product becomes incorporated within the polymer but, as it lacks correct configuration, the resultant clot is friable and subsequent clot retraction is defective. Bang, Fletcher, Alkjaersig, and Sherry (1962) have studied the electron microscopic features of this defective fibrin mesh. Excessive accumulation of these relatively large breakdown moieties may ultimately block further polymerization, and indeed, may also provoke haemorrhagic episodes by their effect on the vascular endothelium (Fletcher, Alkjaersig, and Sherry, 1962), a point to be borne in mind during the phase of excessive intravascular fibrinolysis induced by thrombolytic therapy (Flute, 1964).

\section{THE FIELD OF ACTION}

If, indeed, there is continuous destruction of fibrinogen in vivo, irrespective of the actual thrombotic deposition of fibrin, then one must question where in the vascular tree this event is taking place. Rheological studies must take account of the 


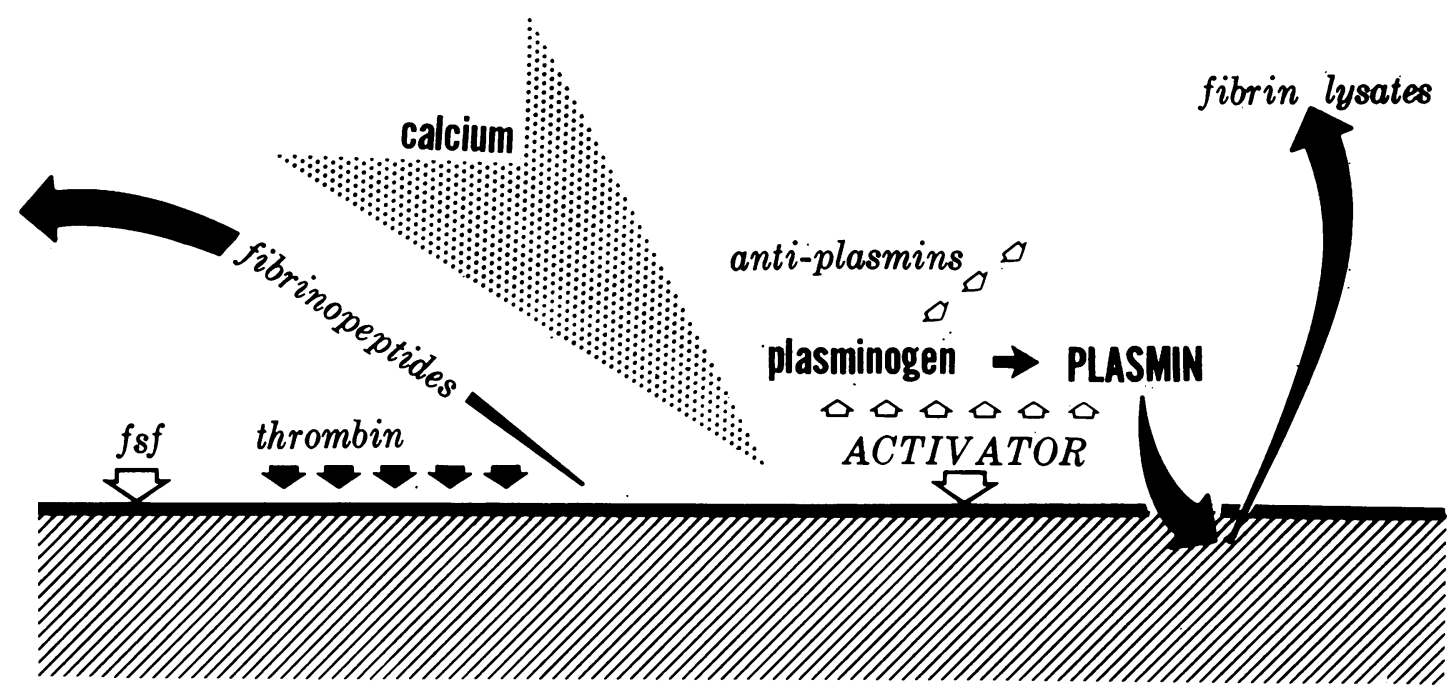

FIG. 5. The surfaces offered by fibrin (shaded) and comprising side-to-side bonded fibrin monomers.

To this, thrombin and activator are specifically adsorbed: plasminogen and the fibrin stabilizing factor ( $f$ sf $)$ may also 3 be attracted. Antiplasmins may be trapped within the clot mesh and thus inhibit plasminogen conversion; the by-products, fibrinopeptides and fibrin lysate polypeptides, may also have a retarding influence. Calcium may have a cardirial role of $\overrightarrow{\vec{c}}$ enhancing thrombin and antiplasmin activity, and serving as a cationic bridge for other protein linkages.

turbulence engendered by arterial pulsation or the eddying where veins receive tributaries: only in capillaries is laminar flow likely to be constant, and in vessels of such small calibre the actual distribution of cell particles is subject to the sigma phenomenon (Scott-Blair, 1958) whereby blood alters its apparent viscosity with changing conditions of flow. Copley (1953, 1962) discusses the significance of laminar flow and its production of a relatively immobile outer, intimal, zone of plasma which at its extreme edge may present a single line of fibrinogen molecules. At one time Copley suggested that fibrin itself might be directly opposed to the vessel wall but this has not attracted credence.

Possibly there are two fields of action for the depredations of thrombin and plasmin. In the capillary bed a protracted physiological form of guerrilla skirmishing is dominated by plasmin: here the permeability of the endothelial barrier to encroachment by tissue moieties, the intermittent nature of flow in alternately functioning or stagnant networks, and the relatively greater proportion of plasma to cells induced by the sigma effect may provide an environment optimally designed to cope with the myriad but minor breaches of vascular integrity- 'wear-and-tear'. In the venous or arterial streams, however, which should not normally be stagnant, the greater flow rate, larger proportion of cells to plasma, and the different nature of the vessel walls, allow only isolated forays which, as they are induced by pathological changes, may result in ao local ascendency of thrombin over plasmin polymerization of fibrinogen rather than its lytico destruction. Especially might this be so if inflamm-응 ation of the vein wall or atherosclerotic changes in the arterial intima provide focal points for the $\overrightarrow{\overrightarrow{0}}$ aggregation of platelets.

One might speculate further that the essential difference between these two intravascular fields of action is emphasized during the process of ageing with senescence, capillary fragility and its attendant:bleeding contrasts with the occlusive tendency in 3 . larger vessels. This does not necessarily conflict with the morphological concept underlying 'fibrinous vasculosis' (Lendrum, 1955, 1963) for this is based on extravascular escape of plasma molecules. Clearly the equilibrium between fibrinolysis and? coagulation in the tissues must be governed by different laws, and the fate suffered by the fibrinogen $\sigma$ molecule can scarcely be comparable. The exercisen in semantics involving the word 'fibrinoid' (Pagel N 1951; Movat and More, 1957; Lendrum, Fraser, $\sigma$ Slidders, and Henderson, 1962) is due in large measure to a failure to acknowledge that intravascular and extravascular polymerization of fibrinogen need not necessarily and, indeed, can scarcely ever, be identical.

Extravascular (tissue) proteolysis, as opposed to

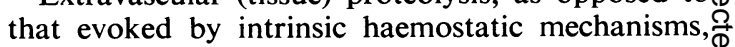
may involve a sequence of different yet related $\stackrel{0}{\sigma}$ 
enzymic reactions. Although not germane to this review, it is of interest to refer to work on the release of tissue plasminogen activator (Albrechtsen, 1957) and that in milk (Astrup and Sterndorff, 1953), saliva (Albrechtsen and Thaysen, 1955), and tears (Storm, 1955). Von Kaulla (1963) speculates upon the importance of interaction between components of the fibrinolytic system in the process of fertilization, as seminal fluid contains plasminogen activator (von Kaulla and Shettles, 1953). The significance of lysis within the lymph system, which contains a substantial proportion of the body fibrinogen pool, has not yet been assessed, but in the joint cavities Lack (1963) has made a close study of the importance of fibrinolysis in relation to joint function and synovial integrity.

\section{LOCAL FEATURES}

The dynamic equilibrium between coagulation and fibrinolysis allows the clotting system to correct endothelial defects with a haemostatic fibrin seal while the fibrinolytic system prevents further progress to occlusion by removing any fibrin scaffolding once the endothelium is repaired.

There remain three local features which must be brought into any consideration of the fibrinolytic maintenance of vascular patency: the nature and function of endothelium (Altschul, 1954; Warren, 1964), the part played by platelets (Holemans and Gross, 1961), and the presence of proteins other than those directly involved in haemostasis, chylomicrons and low-density lipoproteins (Greig, 1956; Pappenhagen, Kopel, and Olwin, 1963; Howell, 1964a and b).

THE ENDOTHELIUM Albrechtsen (1957) and Todd (1959) have shown plasminogen activator activity in the intact vessel wall, and Warren (1963) has clearly demonstrated this to be present in isolated endothelial cells themselves. In his review of endothelial ultrastructure, Palade (1961) stresses the physiological necessity for an ample and continuous exchange across the capillary wall between plasma and interstitial fluid. In this context this implies movement inwards of plasminogen activator and the reverse flow of degradation products, fibrin monomer, or the partially polymerized fibrinogen referred to by Copley (1962). An earlier belief in mural pores has been superseded by the electron microscopic demonstration of sack-like calveolae intracellulares which open onto the cell surface or move across the cytoplasm. Any such carrier structure bears a resemblance to the lysosome (de Duve, 1963) and may thus be related to the activity of intracellular acid hydrolases. Lack (1963) has demonstrated that certain lysosomes contain plasminogen activator, a finding which may be equated with the plasminogen activator properties of disintegrated leucocytes reported by Gans (1964) and long recognized in abscess formation. Endothelial lysosomes, if they exist, by being particularly susceptible to local hypoxia or damage, might actively contribute to the induction of capillary permeability (Miles and Wilhelm, 1960).

Plasma kinins, which evoke pain, are released into the plasma after surface contact stimulation (Armstrong, Jepson, Keele, and Stewart, 1957). One of these, kallikrein, is an active form of an inactive plasma precursor, kallikreinogen, which is similar in many respects to plasminogen. Kallikrein may be an enzyme which is quite distinct from plasmin, or it might be this latter moiety after it has been modified by some inhibitor or activator, consequent upon contact; its formation is thus intimately concerned with factor XII. Kallikrein differs from plasmin as it does not attack casein or fibrin, nor is it inhibited by epsilon aminocaproic acid (Eisen, 1963). One might speculate upon the relationship between the normal endothelial surface, the contact factors, plasma kinins, and permeability factors: but there is little objective physiological evidence upon which to base this conjecture.

PLATELETS The effect of fibrinolysis on these cell fragments depends on whether they are intact, when their surface adsorptive qualities may contribute calcium ions and certain protein molecules, or disrupted. Their being intact will also influence fibrinolysis according to whether they remain discrete and mobile, or become sticky, undergo viscous metamorphosis and clump.

Their function should only be assessed having regard to their simultaneous involvement in clotting and in clot retraction. Johnson and Schneider (1953) first showed platelets to contain an antiplasmin, inhibiting fibrinolysis. Bierstedt (1958) found isolated intact platelets to possess an opposite, accelerating, effect which Holemans and Gross (1961) believe to be due to surface adsorption of a proactivator which they differentiate from plasminogen activator.

Platelets do not carry or contain measurable plasminogen but during the phenomenon of clumping they may become intimately linked with fibrinogen-.'platelet fibrinogen' (Johnson, Smathers, and Schneider, 1952). Electron microscopy of artificially induced platelet aggregates (Poole, 1959) and platelet thrombi (Poole, French, and Cliff, 1963; Rodman, Mason, and Brinkhous, 1963) does not necessarily show fibrin to be present between adjacent cell margins, and their agglomeration in the so-called 'white bodies' occasionally seen to circulate in physiological circumstances still requires 
explanation. Johnson and McKenna (1963) have shown that the clotting of relatively low platelet concentrations forms a coarse fibrin network, whilst very high platelet concentrations form significantly less fibrin without clot retraction.

The role of platelets in the lysis of formed thrombi is plainly different from any function they may serve in the moving plasma stream.

LIPOPROTEINS In vitro, low-density lipoproteins, chylomicron suspensions, and phospholipid preparations may, in certain circumstances, inhibit fibrinolysis; and, in vivo, the prolongation of the clot lysis time has been observed by several workers after alimentary hyperlipaemia has been induced by saturated fats. Whether this is merely a function of surface adsorption, or whether electro-negative lipid moieties physically interfere with the contact between interacting protein molecules, has yet to be explicated. The demonstration of these effects of plasma lipids has led to speculation about the relation between inhibited physiological fibrinolysis and the incidence of atherosclerosis: among others, Merskey, Gordon, and Lackner (1960) and Howell (1964b) have shown a somewhat greater fibrinolytic potential in the Negro as compared with European controls, and attention has thus been focused on possible racial differences in plasma lipid components or their concentrations, and on the incidence of myocardial ischaemia. The epidemiological or sociological implications of these findings lie more in the province of atherosclerosis research but the subject, as it relates to fibrinolysis, has been reviewed recently by Howell (1964b).

\section{CONCLUSIONS}

Whatever may be true of the sequence of events in pathological thrombosis, little is known about the physiological control of haemostasis. The dynamic interaction of protein molecules in solution, aided and abetted by ionic calcium, is clearly influenced by surface adsorption. This can, perhaps, be more readily appreciated in relation to the large surfaces of cells and the vessel lining, but all the moieties taking part present surfaces. It remains to be seen whether macromolecules, such as lipoproteins, fibrinogen itself, or fibrinogen breakdown products, are capable of exerting a significant physical influence upon each other, but it seems very likely that they can. Effective haemostasis thus may be dependent upon the ability of enzymic moieties to collide with their substrates in the plasma: nature has provided the mammalian circulation with an excess of the latter together with a potential excess of the former. But this plenitude is not so great that physical neutralization by inhibitor or non- reacting molecules cannot occasionally upset the equilibrium.

The work at St. George's Hospital referred to in this paper was made possible by grants from the Medical 을 Research Council and from the St. George's Hospital Research Fund.

\section{REFERENCES}

Ablondi, F. B., and Hagan, J. J. (1957). Proc. Soc. exp. Biol. (N. Y.), 95, 195.

Albrechtsen, O. K. (1957). Brit. J. Haemat., 3, 284.

, and Thaysen, J. H. (1955). Acta physiol. scand., 35, 138.

Alkjaersig, N., Fletcher, A. P., and Sherry, S. (1958). J. biol. Chem., 233, 86.

Fletcher, A. P., and Sherry, S. (1962). J. clin. Invest., 41, 917.

Allwood, M. J., and Lewis, G. P. (1963). J. physiol. (Lond.), 166, 47P. I Altschul, R. (1954). Endothelium. Its Development, Morphology, Function, and Pathology. Macmillan, New York.

Ambrus, C. M., and Markus, G. (1960). Amer. J. Physiol., 199, 491. Back, N., Ambrus, J. L., and Markus, G. (1959). Fed. Proc., 18, 364. 음 Armstrong, D., Jepson, J. B., Keele, C. A., and Stewart, J. W. (1957). J. Physiol. (Lond.), 135, 350.

Astrup, T. (1962). In Proc. 8th Cengr. europ. Soc. Haemat., pt. 2, ch. 439, Vienna 1961. Karger, Basel.

, and Mullertz, S. (1952). Arch. Biochem., 40, 346.

, and Permin, P. M. (1947). Nature (Lond.), 159, 681. and Sterndorff, I. (1953). Proc. Soc. exp. Biol. (N.Y.), 84, 605.

Bang, N. U., Fletcher, A. P., Alkjaersig, N., and Sherry, S. (1962). ( J. clin. Invest., 41, 935.

Bierstedt, P. (1958). In 6th Congr. europ. Soc. Haemat. Trans., pt. 2, $\vec{c}$ p. 483. Copenhagen, 1957. Karger, Basel.

Bickford, A. F., and Sokolow, M.(1961). Thrombos. Diathes. haemorrh. (Stuttg.), 5, 480.

Biggs, R., Macfarlane, R. G., and Pilling, J. (1947). Lancet, 1, 402.

Blix, S. (1962). Acta med. scand., 172, suppl. 386.

Bruce, Sally (1964). J. clin. Path., 17, 282.

Celander, D. R., and Guest, M. M. (1957). Arch. Biochem., 72, 176.

Christensen, L. R. (1949). J. clin. Invest., 28, 163.

Clement, W. E., and McNicol, G. P. (1959). J. clin. Path., 12, 544.

Cohen, S., Holloway, R. C., Matthews, C., and McFarlane, A. S. (1956). Biochem. J., 62, 143.

Copley, A. L. (1953). In 19th int. Physiol. Congr. (abstracts of communication), p. 280. Montreal.

(1962). In Proc. 8th Congr. europ. soc. Haemat., pt. 2, ch. 357 . Vienna 1961. Karger, Basel.

Davies, M. C., and Englert, M. E. (1960). J. Biol. Chem., 235, 1011.

de Duve, C. (1963). In Lysosomes. A Ciba Foundation Symposium, p. 1. Churchill, London.

Donaldson, V. H. (1960). J. Lab. clin. Med., 56, 644.

Eisen, V. (1963). J. Physiol. (Lond.), 166, 496.

Fearnley, G. R. (1953). Nature (Lond.), 172, 544.

(1961). Lancet, 1, 992.

_, Balmforth, G. V., and Fearnley, E. (1957). Clin. Sci., 16, 645. and Lackner, R. (1955). Brit. J. Haemat., 1, 189.

Fletcher, A. P., Alkjaersig, N., and Sherry, S. (1959). J. clin. Invest. 38, 1096.

$\longrightarrow,-$, (1962). Ibid., 41, 896.

Flute, P. T. (1960). In Proc. 7th Congr, europ. Soc. Haemat., pt. 2 , p. 894, London 1959. Karger, Basel.

(1964). Proc. roy. Soc. Med., in the press.

Gans, H. (1964). Thrombos. Diathes. haemorrh. (Stuttg.), 10, 379.

Green, J., and Thompson, W. B. (1962). Biochem. J., 84, 74P.

Greig, H. B. W. (1956). Lancet, $2,16$.

Hall, C. E., and Slayter, H. S. (1959). J. biophys. biochem. Cytol., 5, 11 .

Hammond, J. D. S., and Verel, D. (1959). Brit. J. Haemat, 5, 431.

Hawkey, C. M., and Stafford, J. L. (1964). J. clin. Path., 17, 175.

Holemans, R. (1963). Lancet., 2, 364

, and Gross, R. (1961). Thrombos. Diathes. haemorrh. (Stuttg.), 6, 196

Howell, M. B. (1963). J. clin. Path., 16, 289

(1964a). In Second Fibrinolysis Workshop. J. clin. Path., 17, 310. (1964b). Fibrinolysis. Brit. med. Bull., 20, (3), in the press.

Iatridis, S. G., and Ferguson, J. H. (1961). Thrombos. Diathes. haemorrh. (Stuttg.), 6, 411.

__, _-, (1962). J. clin. Invest., 41, 1277.

- —- (1963). J. appl. Physiol., 18, 337.

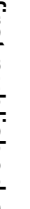

$\overrightarrow{0}$

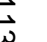

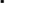


Johnson, S. A., and McKenna, J. L. (1963). Thrombos. Diathes. haemorrh. (Stuttg.), 9, 102.

_- and Schneider, C. L. (1953). Science, 117, 229.

-, Smathers, W. M., and Schneider, C. L. (1952). Amer. J. Physiol., 170,631 .

Keele, C. A. (1957). Proc. Roy. Soc. Med., 50, 477.

Kline, D. J. (1960). Amer. J. Cardiol., 6, 398.

Kwaan, H. C., Lo, R., and McFadzean, A. J. S. (1957). Clin. Sci., 16, 241.

Lack, C. H. (1963). Personal communication.

Laki, K. (1951). Arch. Biochem., 32, 317. (1962). Sci. Amer., 206, 60.

Lendrum, A. C. (1955). J. clin. Path., 8, 180.

—, Fraser, D. S., Slidders, W., and Henderson, R. (1962). Ibid., 15, 401. (1963). Canad. med. Ass. J, 88, 442.

Lewis, G. P. (1962). In British Postgraduate Medical Federation, The Scientific Basis of Medicine (Annual Review), p. 242.

Lewis, J. H., Ferguson, E. E., and Schoenfield, C. (1961). J. Lab. clin. Med., 58, 247.

Lorand, L. (1961). In Anticoagulants and Fibrinolysins, edited by R. L. MacMillan and J. F. Mustard, p. 333. Pitman, London.

Macfarlane, R. G. (1945). Proc. roy. Soc. Med., 38, 399.

- (1964). Nature, Lond. 202, 498.

and Biggs, R. (1946). Lancet, 2, 862.

McNicol, G. P., Douglas, A. S., and Bayley, C. (1962). Lancet, 2, 1297.

Madden, R. E., and Gould, R. G. (1952). Fed. Proc., 11, 252.

Margolis, J. (1958a). Nature (Lond.), 181, 635.

- (1958b). J. Physiol. (Lond), 144, 1.

Merskey, C., Gordon, H., and Lackner, H. (1960). Brit. med. J., 1, 219.

Miles, A. A., and Wilhelm, D. L. (1960). In The Biochemical Response to Injury. A Symposium edited by H. B. Stones, p. 51. Blackwell, Oxford.

Mill, P. J., Elder, J. M., Miles, A. A., and Wilhelm, D. L. (1958). Brit. J. exp. Path., 39, 343.

Movat, H. Z., and More, R. H. (1957). Amer. J. clin. Path., 28, 331.

Niewiarowski, S., and Prou-Wartelle, O. (1959). Thrombos. Diathes. haemorrh. (Stuttg.), 3, 593.

Nilsson, I. M., and Olow, B. (1962). Ibid., 8, 297.

Norman, P. S. (1958). J. exp. Med., 108, 53.

, and Hill, B. M. (1958). Ibid., 108, 639.

Oncley, J. L., Melin, M., Richert, D. A., Cameron, J. W., and Gross, P. M. Jr. (1949). J. Amer. chem. Soc., 71, 541.

Pagel, W. (1951). J. clin. Path., 4, 137.

Palade, G. E. (1961). Circulation, 24, 368.

Pappenhagen, A. R., Kopel, J. L., and Olwin, J. H. (1963). Thrombos. Diathes. haemorrh. (Stuttg.), 9, 164.

Poole, J. C. F. (1959). Quart. J. exp. Physiol., 44, 377.

- French, J. E., and Cliff, W. J. (1963). J. clin. Path., 16, 523.

Ratnoff, O. D. (1953). J. clin. Invest., 32, 473.

-, and Colopy, J. E. (1955). Ibid., 34, 602.

, Davie, E. W., and Mallett, D. L. (1961). Ibid., 40, 803.

- and Rosenblum, J. M. (1958). Amer. J. Med., 25, 160.

Rodman, N. F. Jr., Mason, R. G., and Brinkhous, K. M. (1963). Fed. Proc., 22, 1356.

Roos, J. (1957). Thrombos. Diathes. haemorrh. (Stuttg.), 1, 471.

Saameli, K., and Eskes, T. K. A. B. (1962). Amer. J. Physiol., 203, 261.

Sawyer, P. N., Plate, J. W., and Weldon, C. S. (1953). Ibid., 175, 108.

Sawyer, W. D., Fletcher, A. P., Alkjaersig, N., and Sherry, S. (1960). J. clin. Invest., 39, 426.

Scheraga, H. A. (1958). Ann. N.Y. Acad. Sci., 75, 189.

Scott-Blair, G. W. (1958). Rheologica Acta, 1, 123.

Sgouris, J. T., Inman, J. K., McCall, K. B., Hyndman, L. A., and Anderson, H. D. (1960). Vox Sang. (Basel), 5, 357.

Sherry, S., Fletcher, A. P., and Alkjaersig, N. (1959a). Physiol. Rev., 39, 343.

—, Lindemeyer, R. I., Fletcher, A. P., and Alkjaersig, N. (1959b). J. clin. Invest., 38, 810.

Shulman, N. R., and Tagnon, H. J. (1950). Ibid., 186, 69

Shulman, S., Alkjaersig, N., and Sherry, S. (1958). J. biol. Chem., 233,91 .

Sjoerdsma, A., and Nilsson, I. M. (1960). Prcc. Soc. exp. Biol. (N.Y.), $103,533$.

Spector, W. G. (1957). J. Path. Bact., 74, 67.

Storm, O. (1955). Scand. J. clin. Lab. Invest., 7, 55.

Tagnon, H. J. (1942). J. Lab. clin. Med., 27, 1119.

Tillett, W. S., and Garner, R. L. (1933). J. exp. Med., 58, 485.

Todd, A. S. (1959). J. Path. Bact., 78, 281.

Troll, W., Sherry, S., and Wachman, J. (1954). J. biol. Chem., 208, 85.

von Kaulla, K. N. (1963). The Chemistry of Thrombolysis: Human Fibrinolytic Enzymes, p. 289. Thomas, Springfield, Illinois. von Kaulla, K. N. and Shettles, L. B. (1953). Proc. Soc. exp. Biol. (N.Y.), $83,692$.

Warren, B. A. (1963). Brit. J. exp. Path., 44, 365.

- (1964). The Structure and Function of Endothelium. Ph.D. Thesis, Oxford University.

Williams, J. R. B. (1951). Brit. J. exp. Path., 32, 530.

\section{Appendix}

This has been a review of the intrinsic mechanisms governing fibrinolysis; hence only a passing reference has been made to extrinsic or tissue activation, and synthetic inhibitors such as epsilon-aminocaproic acid have not been discussed. Since thrombolytic therapy became feasible, however, these subjects have particular clinical significance; moreover, pathologists may soon be called upon to provide adequate laboratory surveillance, failing which this form of treatment should never be undertaken.

It would be premature to select or to recommend methods of fibrinolysin assay: this subject is still relatively new, and modifications or improvements have yet to be assimilated. In experienced hands, some techniques can provide reproducible results, but probably the most important single feature is the selection of reagents which are as free as possible from contamination by other factors capable of influencing proteolysis; and this selection is governed by the facility of local commercial supply. The following recent British references, which are additional to those in the main text, are cited by title for those who wish to read further into the technical aspects of this subject.

\section{GENERAL TECHNIQUE}

The investigation of plasminogen activators using a quantitative fibrinolytic method (Anderson, 1962). Determination of fibrinolytic activity of whole blood with special reference to the effects of exercise and fat feeding (Billimoria, Drysdale, James, and Maclagen, 1959). The release of thrombin from fibrin by fibrinolysis (Bloom, 1962). Some physico-chemical properties of human fibrinogen (Caspary and Kekwick, 1957). The 'fibrinolytic potential' as a simple measure of spontaneous fibrinolysis (Chakrabarti and Fearnley, 1962). Increase of blood fibrinolytic activity by testosterone (Fearnley and Chakrabarti, 1962). Purification of fibrinogen (Kekwick, Mackay, Nance, and Record, 1955). An evaluation of the euglobulin method for the determination of fibrinolysis (Kowalski, Kopec, and Niewiarowski, 1959). Activation of endogenous plasma proteolytic enzymes with consequent production of pharmacologically active polypeptides (MacKay, Maycock, and Combridge, 1962). The effect of alimentary lipaemia on plasma fibrinolytic activity (Ogston and Fullerton, 1962). Estimation of plasminogen in biological fluids by agar/fibrinogen gel diffusion (Thornes, 1963).

\section{THROMBOLYTIC THERAPY}

Arterial occlusion treated with streptokinase (Clark, Hawkey, Howell, Rees, and Stubbs, 1964). Popliteal artery thrombosis treated with streptokinase (Cotton, Flute, and Tsapogas, 1962). Fibrinolytic therapy of coronary thrombosis (Dewar, Stephenson, Horler, 
Cassells-Smith, and Ellis, 1963). The clinical assessment of fibrinolysis (Flute, 1963). The laboratory control of thrombolytic therapy (Hawkey and Howell, 1964a). Intravenous streptokinase in the treatment of retinal vascular occlusion (Hawkey and Howell, 1964b). Thrombolytic therapy (McNicol, 1963). Studies in vitro and in vivo of a preparation of urokinase (McNicol, Gale, and Douglas, 1963a). Treatment of peripheral arterial occlusion by streptokinase perfusion (McNicol, Reid, Bain, and Douglas, 1963b). The effects of chlorpropamide on intermittent claudication and fibrinolysis (Tsapogas, Cotton, Flute, and Murray, 1962a). Lysis of experimental thrombi by streptokinase (Tsapogas, Flute, Cotton, and Milroy, 1962b). Feasibility of adequate thrombolytic therapy with streptokinase in peripheral arterial occlusions (Verstraete, Amery, and Vermylen, 1963).

This list, which is by no means exhaustive, can be supplemented by reference to Human Blood Coagulation (Biggs and Macfarlane, 3rd ed., 1962), Anticoagulant Therapy (Douglas, 1962) and the symposium on fibrinolysis in this Journal (J. clin. Path., 1964, 17, 305-370). A chapter on the fibrinolytic enzyme system (McNicol and Douglas) is to be included in the forthcoming Recent Advances in Clinical Pathology (Series IV, 1964) and a complete issue of the British Medical Bulletin (Vol. 20, No. 3, September, 1964) is devoted to this subject.
APPENDIX REFERENCES

Anderson, A. J. (1962). Biochem. J., 83, 7P.

Billimoria, J. D., Drysdale, J., James, D. C., and Maclagen, N. F (1959). Lancet, 2, 471.

Bloom, A. L. (1962). Brit. J. Haemat., 8, 129.

Caspary, E. A., and Kekwick, R. A. (1957). Biochem. J., 67, 41.

Chakrabarti, R., and Fearnley, G. R. (1962), J clin. Path., 15, 228.

Clark, M. L., Hawkey, C. M., Howell, M. B., Rees, R. S. O., andu Stubbs, J. (1964). Postgrad. med. J., in the press.

Cotton, L. T., Flute, P. T., and Tsapogas, M. J. C. (1962). Lancet, 2, $\overrightarrow{0}$ 1081.

Dewar, H. A., Stephenson, P., Horler, A. R., Cassells-Smith, A. J.ت己 and Ellis, P. A. (1963). Brit. med. J., 1, 915.

Fearnley, G. R., and Chakrabarti, R. (1962). Lancet, 2, 128.

Flute, P. T. (1963). Proc. roy. Soc. Med., 56, 411.

Hawkey, C. M., and Howell, M. B. (1964a). J. clin. Path., 17, 287. (1964b). Ibid., 17, 363.

Kekwick, R. A., Mackay, M. E., Nance, N. H., and Record, B. R. S, (1955). Biochem. J., 60, 671.

Kowalski, E., Kopec, M., and Niewiarowski, S. (1959). J. clin. Path. 12, 215.

MacKay, M., Maycock, W. d'A., and Combridge, B. S. (1962)음 Nature, (Lond.), 195, 1206.

McNicol, G. P. (1963). Proc. roy. Soc. Med., 56, 414.

Gale, S. B., and Douglas, A. S. (1963a). Brit. med. J., 1, 909. \& Reid, W., Bain, W. H., and Douglas, A. S. (1963b). Ibid., 1, 1508ब

Ogston, D., and Fullerton, H. W. (1962). Ibid., 2, 1288.

Thornes, R. D. (1963). J. clin. Path., 16, 87.

Tsapogas, M. J., Cotton, L. T., Flute, P. T., and Murray, J. G (1962a). Lancet, 1, 1213.

Surg., 50, 334.

Verstraete, M., Amery, A., and Vermylen, J. (1963). Brit. med. J., 1ळூ 1499. 